\title{
A new velvet ant genus Arkaditilla (Hymenoptera, Mutillidae, Trogaspidiini) from the Oriental Region, with review of species
}

\author{
Juriya Okayasu ${ }^{1,2}$ \\ I Entomological Laboratory, Faculty of Agriculture, Ehime University, Tarumi 3-5-7, Matsuyama, 790-8566, \\ Japan 2 Systematic Entomology, Graduate School of Agriculture, Hokkaido University, Sapporo, 060-8589, Japan \\ Corresponding author: Juriya Okayasu (mutiphiidae@gmail.com) \\ Academic editor: M. Proshchalykin | Received 15 May 2021 | Accepted 23 June 2021 | Published 24 August 2021 \\ http://zoobank.org/5F83EC63-7C79-47FD-BD29-E7A2B9328518 \\ Citation: Okayasu J (2021) A new velvet ant genus Arkaditilla (Hymenoptera, Mutillidae, Trogaspidiini) from the \\ Oriental Region, with review of species. In: Proshchalykin MYu, Gokhman VE (Eds) Hymenoptera studies through \\ space and time: A collection of papers dedicated to the $75^{\text {th }}$ anniversary of Arkady S. Lelej. Journal of Hymenoptera \\ Research 84: 145-168. https://doi.org/10.3897/jhr.84.68709
}

\begin{abstract}
A new Old World genus in the tribe Trogaspidiini Bischoff, 1920, Arkaditilla gen. nov., is described based on male morphology. Six species are recognized in this genus: A. bagrada (Cameron, 1902), comb. nov. (Indonesia, Malaysia), A. depressicornis (Mickel, 1935), comb. nov. (Malaysia), A. frim sp. nov. (Malaysia), A. gibba sp. nov. (Indonesia), A. leleji sp. nov. (Indonesia), and A. nallinia (Zavattari, 1914), comb. nov. (Indonesia). The species of this new genus were formerly placed in the genus Krombeinidia Lelej, 1996, but they are differentiated from it and other genera by having a unique set of morphological character states, such as the mandible inner margin expanded, forming subbasal tooth; the paramere antero-ventrally serrate; and the digitus dorsal margin lamellate. A key to species of Arkaditilla is provided.
\end{abstract}

\section{Keywords}

Aculeata, distribution, new species, Southeast Asia, taxonomy

\section{Introduction}

The tribe Trogaspidiini Bischoff, 1920 has the greatest species diversity of the four tribes of the subfamily Mutillinae (Pagliano et al. 2020). The eastern Oriental species of this tribe were assigned to the subgenus Trogaspidia Ashmead, 1899 of the New

Copyright Juriya Okayasu. This is an open access article distributed under the terms of the Creative Commons Attribution License (CC BY 4.0), which permits unrestricted use, distribution, and reproduction in any medium, provided the original author and source are credited. 
World genus Timulla Ashmead, 1899 by Mickel (1933a, b, 1934, 1935), but Invrea (1954) resurrected Trogaspidia to full genus status. Chen (1957) transferred some species of Trogaspidia sensu Mickel to Smicromyrme Thomson, 1870. Lelej $(1995,1996$ a) and Lelej and Yamane (1992) reclassified the Smicromyrme-Trogaspidia assemblage, recognized new genera for species of Smicromyrme sensu Chen, and arranged them in the subtribe Petersenidiina Lelej, 1996. Along with this, East Asian members of Trogaspidia sensu Chen were divided into five genera constituting Trogaspidiina Bischoff, 1920. Those two subtribes were included in Trogaspidiini, but later regarded as separate tribes by Lelej and Nemkov (1997). However, Brothers and Lelej (2017) found that Petersenidiini was a paraphyletic group and synonymized it with Trogaspidiini. Consequently, Trogaspidiini is now represented by 13 genera in the eastern Oriental Region (Brothers and Lelej 2017; Pagliano et al. 2020). The species of this tribe are sometimes difficult to place in those previously established genera, because the "petersenidiine" genera exhibit various intermediate character states between Petersenidiini and Trogaspidiini (Brothers and Lelej 2017). Also, the species of Trogaspidiini show great interspecific morphological variations, making genus delimitation difficult (e.g. Okayasu et al. 2021). Revision of genus-level classification is thus required, and generic placement of described species, which are mostly known from the old literature only (Okayasu et al. 2021), needs to be extensively reviewed.

In this study, I present a review of the Krombeinidia Lelej, 1996 species with male flagellomere 1 depressed, K. depressicornis (Mickel, 1935) and K. nallinia (Zavattari, 1914), because Mickel's (1935) key suggests they are the only species with that trait in the former Petersenidiini. I also examined K. bagrada (Cameron, 1902), which was placed near those two species by Mickel (1935) although it has the flagellomere 1 cylindrical, and three undescribed species that are similar to $K$. depressicornis and $K$. nallinia. As discussed below, those "Krombeinidia" species share additional character states that are their potential synapomorphies, so the new genus Arkaditilla is proposed to accommodate them.

\section{Material and methods}

The following abbreviations are used to denote institutes housing the material discussed in this study:

EUM Ehime University Museum, Matsuyama, Japan;

FRIM Forest Research Institute Malaysia, Selangor, Malaysia;

NARO Insect Museum, National Agriculture and Food Research Organization, Tsukuba, Japan (former Institute for Agro-Environmental Sciences);

TKPM Tokushima Prefectural Museum, Tokushima, Japan;

TUA Laboratory of Entomology, Tokyo University of Agriculture, Atsugi, Japan.

In the synonymic lists and the material examined sections, abbreviations for depository and additional or corrected data by the author are given in square brackets. New records are asterisked $(*)$. 
Specimens were observed under a Leica S8APO stereomicroscope (10-80× magnification). Photo images were taken with a Nikon Digital Sight DS-Fil camera attached to a Leica S8APO, and stacked using CombineZM software (Hadley 2008). Measurements of specimens were taken twice, in order to reduce measurement errors, and the mean value was indicated in the description. The distributional maps (Figs 73-76) were generated using SimpleMappr (Shorthouse 2010). Figures were edited with Adobe Photoshop software and Adobe Illustrator software. Terminology mostly follows the Hymenoptera Anatomy Consortium (2021) for the general morphology, and Harris (1979) for the integument sculpture.

The following abbreviations are used:

\begin{tabular}{|c|c|c|c|}
\hline \multirow{6}{*}{$\begin{array}{l}\text { F } \\
\text { LOD } \\
\text { MOD } \\
\text { OD }\end{array}$} & flagellomere; & OOD & ocular-ocellar distance (betweer \\
\hline & lateral ocellus diameter; & & lateral ocellus and eye); \\
\hline & median ocellus diameter; & POD & posterior ocellar distance (be \\
\hline & interocellar distance (between & & ween lateral ocelli); \\
\hline & median and lateral ocellus); & & metasomal sternum; \\
\hline & & $\mathbf{T}$ & metasomal tergum. \\
\hline
\end{tabular}

Prior to observation, the male genitalia were soaked in a $10 \%$ potassium hydroxide $(\mathrm{KOH})$ solution without heating for one to three hours to dissolve muscles, and subsequently soaked in a $25 \%$ acetic acid solution to neutralize. Then, the genitalia were observed in a Petri dish filled with $70 \%$ ethanol under a stereomicroscope. Further dissection was done using forceps and a minuten pin attached to a handle. Dissected parts were photographed under incident light in a Petri dish filled with glycerin except that the penis valves were placed on a glass slide with a drop of glycerin and a cover glass. After examination, all dissected parts were stored in micro vials filled with glycerin and pinned with their respective specimens.

\section{Results}

\section{Arkaditilla gen. nov.}

http://zoobank.org/A07954E6-26EB-4494-860C-51F96F27D2C1

Figures 1-76

Mutilla (in part): Cameron 1902: 76, ơ; Zavattari 1914: 100, §.

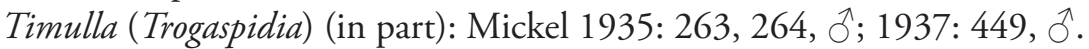

Krombeinidia (in part): Lelej 1996a: 11, §.

Petersenidia (in part): Lelej 1996b: 94, 95, $\widehat{0}$.

Diagnosis. Male. Frons punctate; vertex roundly sloping posteriorly; postgenal bridge flattened; hypostomal carina simple, without denticle; clypeus dorsally elevated; prementum without tubercle. Mandible apically bidentate, ventrally excised into basal tooth (Figs 19-24); inner margin expanded, forming subbasal tooth (Figs 13-18); 
dorso-lateral carina sharp, not crooked. Scape ventrally with two longitudinal carinae, densely punctate or mostly smooth with sparse punctures apically between carinae (Figs 25, 27, 29, 31, 33, 35); flagellum with yellow or reddish brown ventral markings; F1 longer than F2, depressed (Figs 28, 30, 32, 34, 36) except $A$. bagrada with F1 cylindrical (Fig. 26). Mesosoma black; notaulus present, reaching anterior $1 / 3$ to $1 / 2$ of mesoscutum; parascutal carina forming weakly elevated, rounded tubercle posteriorly; tegula posterior margin slightly protruding over transscutal articulation, not recurved; mesoscutellum evenly convex, puncto-reticulate; mesopleuron divided into dorsal and ventral convexities by transverse groove; propodeum gradually sloping posteriorly, without sublateral longitudinal carina; propodeal dorso-lateral margin without denticles. Pterostigma length subequal to distance between origin of RS on vein SC and proximal base of pterostigma. Protibial spur slender; mesocoxa evenly convex; metacoxa evenly convex with long sparse recumbent setae, without tubercle on inner margin. Metasoma black with segments 1-2 or 3 orange; S2 swollen anteriorly, without lateral felt line (Figs 2, 4, 6, 8, 10, 12); T7 medially with slender longitudinal smooth convex line; S6-S8 without lateral carina; S7 entirely exposed, $0.75 \times$ as long as S8; S8 mostly sclerotized with posterior membranous area evenly convex posteriorly; left and right basiparameres ventro-medial margins connected to form postero-medial tonguelike tubercle (Figs 38, 40, 42, 46, 48); parapenial lobe spatulate, not flexed; ventral portion of basiparamere strongly projecting posteriorly to connect volsella (Figs 49, 52, 55, 58, 61, 64); paramere antero-ventrally serrate (Figs 49, 52, 55, 58, 61, 64); digitus straight, dorsal margin lamellate (Figs 67-72); paracuspis absent, tuberculate or stick-like; penis valves symmetrical, with posterior hook (Figs 50, 51, 53, 54, 56, 57, 59, 60, 62, 63, 65, 66). Female. Unknown.

Type species. Arkaditilla leleji gen. et sp. nov., designated here.

Species included. This genus includes the following six species: Arkaditilla bagra$d a$ (Cameron, 1902), comb. nov., Ô (Indonesia, Malaysia); A. depressicornis (Mickel,

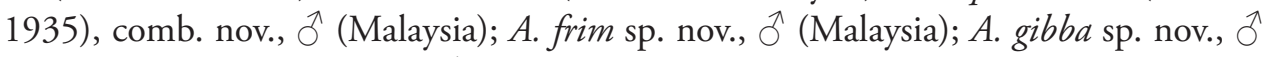
(Indonesia); A. leleji sp. nov., $\widehat{\overbrace{}}$ (Indonesia); A. nallinia (Zavattari, 1914), comb. nov., $\hat{o}$ (Indonesia).

Distribution. Widespread in Sundaland, the Oriental Region (Figs 73-76).

Etymology. I am delighted to name this new genus in honor of Arkady Stepanovich Lelej, a fellow mutillidologist, pioneer of Old World mutillid systematics, and friend, to celebrate his $75^{\text {th }}$ birthday and $50^{\text {th }}$ anniversary of his career since the publication of Lelej (1971), with a common suffix for mutillid genera. Gender feminine.

Biology. This genus is rare in collections; only twelve specimens of $A$. bagrada, nine specimens of $A$. depressicornis, and seven specimens of $A$. nallinia have been reported by previous authors (Cameron 1902; Zavattari 1914; Mickel 1935, 1937; Lelej 1996b). In this study, however, a series of 28 specimens collected in Malaise traps placed in a lowland rain forest at Pasoh Forest Reserve was examined, suggesting greater abundance in forested habitats. See Maetô et al. (1999) for sampling sites.

Remarks. This new genus belongs to the former Petersenidiini Lelej, 1996 by having the penis valves symmetrical, and the species of this genus were formerly placed 
in Krombeinidia Lelej, 1996 (Lelej 1996a) or Petersenidia Lelej, 1992 (Lelej 1996b). However, the males of Arkaditilla differ from those of Krombeinidia and Petersenidia by having the mandible with a subbasal inner tooth (mandibular inner margin entire in Krombeinidia and Petersenidia), the basiparamere antero-ventrally serrate (entire in Krombeinidia and Petersenidia), and the digitus dorsal margin lamellate (digitus cylindrical in Krombeinidia and Petersenidia). Within Trogaspidiini, the males of this new genus and Serendibiella Lelej, 2005 share the mandible with subbasal inner tooth, but the former differs from the latter by having the hypostomal carina without a tubercle (present in Serendibiella), the mesocoxa evenly convex (laterally swollen in Serendibiella), S2 without a lateral felt line (present in Serendibiella), S8 flattened (with sublateral longitudinal carina in Serendibiella), and the penis valves symmetrical (right penis valve longer than left in Serendibiella).

\section{Key to species of Arkaditilla}

1 Scape ventral carinae subparallel (Fig. 25), mostly smooth between them; flagellum at most with F1 apical 1/3 and F2 basal 1/2 yellow; F1 cylindrical (Fig. 26); paracuspis stick-like (Fig. 67). - Indonesia, Malaysia...... A. bagrada (Cameron)

- $\quad$ Scape ventral carinae divergent apically (Figs 27, 29, 31, 33, 35), densely punctate between them; flagellum at least with F1 apical 1/3 and F2 entirely whitish yellow ventrally; F1 depressed (Figs 28, 30, 32, 34, 36); paracuspis absent or slightly tuberculate (Figs 68-72) ............................................... 2

2 Mandible ventrally slightly excised with small basal tooth (Fig. 23); mandible inner margin lamellately expanded near apex (Fig. 17); F1 weakly depressed, F1 height subequal to pedicel diameter (Fig. 34); T3 black; penis valve strongly expanded ventrally on posterior half (Figs 62, 63). - Indonesia .....A. leleji sp. nov.

- $\quad$ Mandible ventrally deeply excised with large basal tooth (Figs 20, 21, 23, 24); mandible inner margin expanded subbasally (Figs 14-16, 18); F1 strongly depressed, F1 height $-0.8 \times$ pedicel diameter (Figs $28,30,32,36$ ); T3 orange; penis valve weakly expanded ventrally (Figs $53,54,56,57,59,60,65,66$ ) ....3

3 Digitus posteriorly slender stick-like (Fig. 39); paracuspis absent (Fig. 68). Malaysia.....

A. depressicornis (Mickel)

- $\quad$ Digitus posteriorly expanded, forming triangular projection (Figs 41, 43, 47); paracuspis slightly tuberculate (Figs 69-72) .......................................... 4

4 Clypeus medially strongly elevated even ventrally; cuspis widened near apex, forming oblique posterior margin (Figs 58, 70). - Indonesia ... A. gibba sp. nov.

- $\quad$ Clypeus dorsally elevated, sloping ventrally; cuspis widened on posterior $1 / 3$ with rounded apex (Figs 55, 64, 69, 72)

5 Mandible with weak subapical and subbasal teeth (Fig. 15); cuspis weakly widened on posterior 1/3 (Figs 55, 69). - Malaysia..... A. frim sp. nov.

- $\quad$ Mandible with sharp subapical tooth and large inner subbasal tooth (Fig. 18); cuspis strongly widened on posterior 1/3 (Figs 64, 72). - Indonesia 
Arkaditilla bagrada (Cameron, 1902), comb. nov.

Figures 1, 2, 13, 19, 25, 26, 37, 38, 49-51, 67, 73

Mutilla bagrada Cameron, 1902: 76, §̂, holotype đิ (Kuching, Sarawak, [Malaysia])

[Natural History Museum, London, UK].

Timulla (Trogaspidia) bagrada: Mickel 1935: 263, ô; 1937: 449, ô.

Krombeinidia bagrada: Lelej, 1996a: 11; 2005: 65; Lo Cascio 2015: 550; Pagliano et al. 2020: 250.

Petersenidia bagrada: Lelej 1996b: 95, ô.

Diagnosis. Male. Clypeus dorsally elevated, sloping ventrally. Mandible with sharp subapical and large inner subbasal teeth (Fig. 13), ventrally deeply excised with large basal tooth (Fig. 19). Scape ventral carinae subparallel, mostly smooth between them (Fig. 25); F1 apical 1/3 and F2 basal 1/2 yellow, F2 apical $1 / 2$ and F3-F11 with ventral reddish brown patch; F1 cylindrical (Fig. 26). T3 orange (Fig. 2); cuspis strongly widened on posterior $1 / 3$ with rounded apex (Figs 49, 67); digitus posteriorly slender stick-like (Fig. 37); paracuspis stick-like (Fig. 67); penis valve weakly expanded ventrally (Figs 50, 51). Female. Unknown.

Material examined. 24 $\hat{}^{2}$. Malaysia: Negeri Sembilan: Pasoh Forest Reserve,

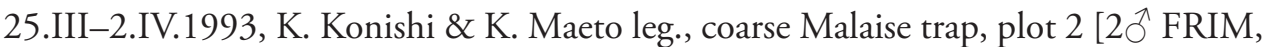

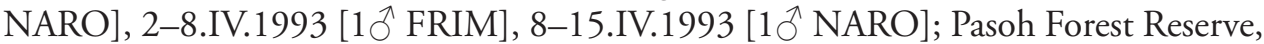
25.III-2.IV.1993, K. Konishi \& K. Maeto leg., fine Malaise trap, plot 2 [2ð FRIM, NARO]; Pasoh Forest Reserve, 26.III-3.IV.1993, K. Konishi \& K. Maeto leg., coarse Malaise trap, plot 4 [1 $ठ^{\Uparrow}$ FRIM], 9-16.IV.1993 [1 $ठ^{\lambda}$ NARO]; Pasoh Forest Reserve,

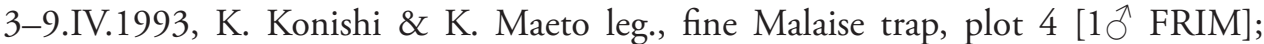
Pasoh Forest Reserve, 26.XI-3.XII.1993, K. Maeto leg., coarse Malaise trap, plot 1 [2へ FRIM, NARO]; Pasoh Forest Reserve, 26.XI-3.XII.1993, K. Maeto leg., coarse Malaise trap, plot 4 [2خ FRIM, NARO]; Pasoh Forest Reserve, 26.XI-3.XII.1993, K. Maeto leg., fine Malaise trap, plot 1 [2へ FRIM, NARO], 10-17.XII.1993 [1ठ FRIM]; Pasoh Forest Reserve, 26.XI-3.XII.1993, K. Maeto leg., fine Malaise trap,

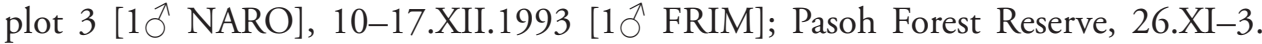
XII.1993, K. Maeto leg., fine Malaise trap, plot 4 [1 ${ }^{\Uparrow}$ NARO], 3-10.XII.1993 [1ठ NARO]; Pasoh Forest Reserve, 3-10.XII.1993, K. Maeto leg., coarse Malaise trap,

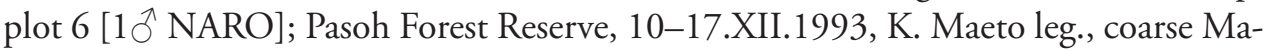

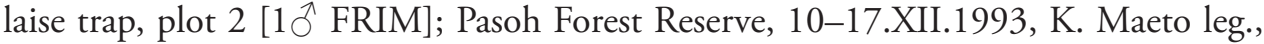

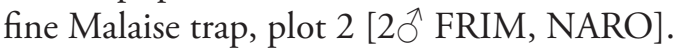

Identification source. Keyed using Mickel (1935) and compared with the original description. No differences were found between the specimens examined herein and Cameron's description.

Distribution. Indonesia: Kalimantan Timur (Lelej 1996b). Malaysia: Negeri Sembilan*, Sarawak (Cameron 1902; Mickel 1937).

Remarks. This is the only species in Arkaditilla with F1 cylindrical, like most species of Mutillinae. Similarly, the species of East Asian genera of the former Petersenidiini, like Krombeinidia, Orientidia Lelej, 1996, Pagdenidia Lelej, 1996, Petersenidia, 


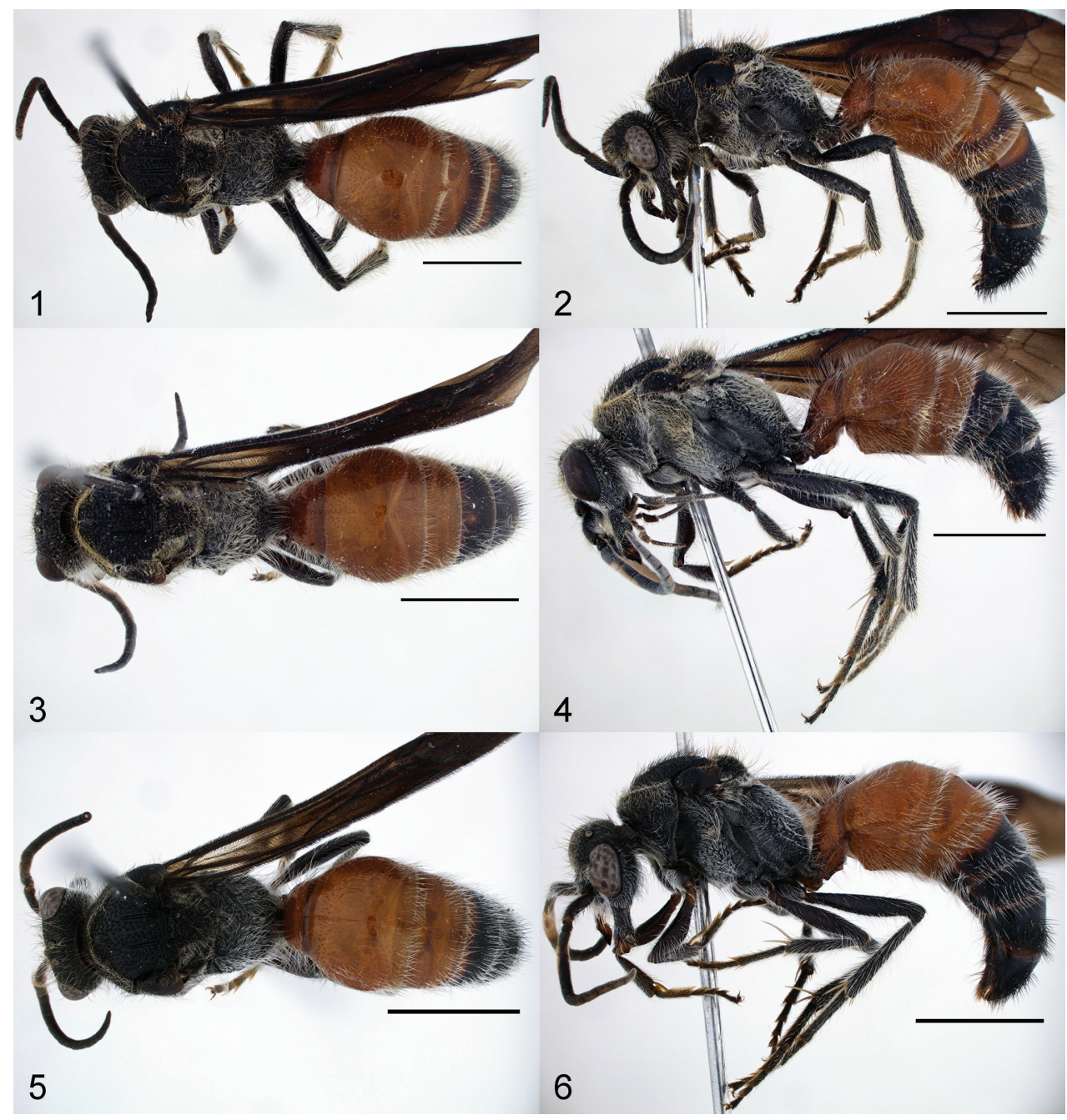

Figures I-6. Arkaditilla spp., $\sigma^{7}$, habitus I, 3, 5 dorsal view 2, 4, 6 lateral view I, 2 A. bagrada (Cameron) 3, 4 A. depressicornis (Mickel) 5, 6 A. frim sp. nov., holotype. Scale bars: $3 \mathrm{~mm}$.

Taiwanomyrme Tsuneki, 1993, and Zavatilla Tsuneki, 1993, have the F1 cylindrical. I presume that this is a plesiomorphic state in Arkaditilla, and A. bagrada is sister to the remaining members of the genus.

Arkaditilla depressicornis (Mickel, 1935), comb. nov.

Figures 3, 4, 14, 20, 27, 28, 39, 40, 52-54, 68, 74

Timulla (Trogaspidia) depressicornis Mickel, 1935: 264, §̂, holotype $\widehat{\partial}$ (Sandakan, [Sabah], Borneo, [Malaysia]) [National Museum of Natural History, Washington D.C., USA]; Mickel 1937: 449, ô. 
Krombeinidia depressicornis: Lelej 1996a: 11; 2005: 66; Lo Cascio 2015: 550; Pagliano et al. 2020: 251.

Petersenidia depressicornis: Lelej 1996b: 94, ठิ.

Diagnosis. Male. Clypeus dorsally elevated, sloping ventrally. Mandible with sharp subapical and large inner subbasal teeth (Fig. 14), ventrally deeply excised with large basal tooth (Fig. 20). Scape ventral carinae divergent apically (Fig. 27), densely punctate between them; F1 apical 1/3, F2-F3, F2-F4, or F2-F5 whitish yellow on ventral half, F5 or F5-F6 with ventral whitish yellow patch, F6-F11 or F7-F11 with ventral dark brown patch; F1 strongly depressed, F1 height $\sim 0.8 \times$ pedicel diameter (Fig. 28). T3 orange (Fig. 4); cuspis weakly widened on posterior $1 / 3$ with rounded apex (Figs 52, 68); digitus posteriorly slender stick-like (Fig. 39); paracuspis absent (Fig. 68); penis valve weakly expanded ventrally (Figs 53, 54). Female. Unknown.

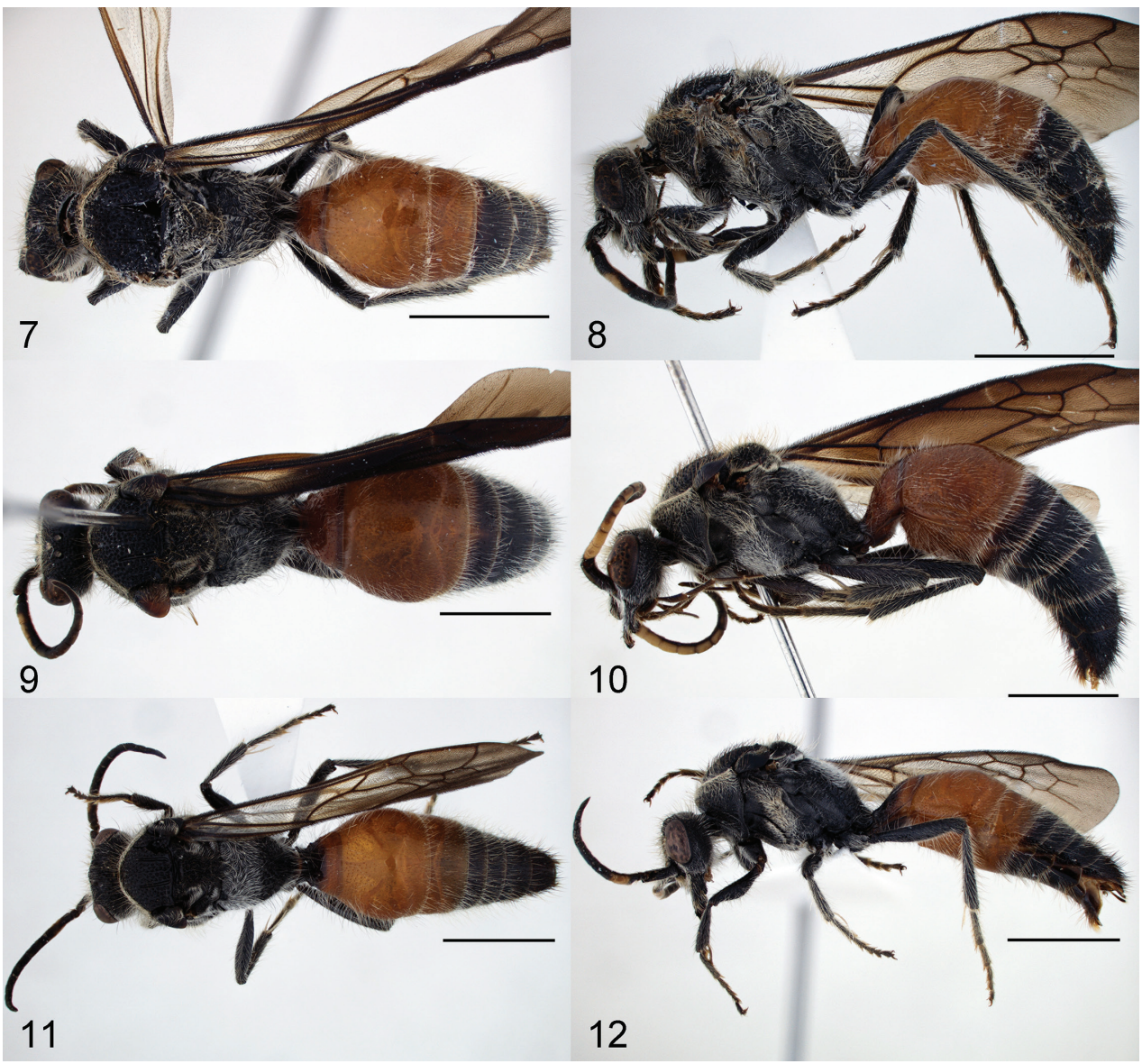

Figures 7-1 2. Arkaditilla spp., Ô, habitus 7, 9, II dorsal view 8, 10, 12 lateral view 7, 8 A. gibba sp. nov., holotype 9, 10 A. leleji sp. nov., holotype II, 12 A. nallinia (Zavattari). Scale bars: $3 \mathrm{~mm}$. 
Material examined. $3 \hat{\partial}$. Malaysia: Negeri Sembilan: Pasoh Forest Reserve,

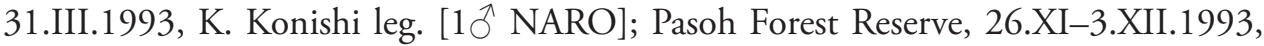

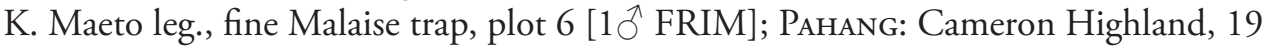
mile, 15.III.2006, K. Takasuka leg. [1 $\overbrace{}^{\text {EUM] }}$.

Identification source. Keyed using Mickel (1935) and compared with the original description. Mickel (1935) described this species as having the F1 apical 1/2 and F2F4 ventrally "pale ferruginous", but the specimens examined herein have the F2-F3, F2-F4, or F2-F5 entirely whitish yellow ventrally.

Distribution. Malaysia: Negeri Sembilan*, Pahang*, Sabah, Sarawak (Mickel 1935, 1937; Lelej 1996b).

Remarks. This species was originally described from Borneo (Mickel 1935) and is newly recorded from Peninsular Malaysia. In this study, this species was primarily recognized by having the F2-F4 ventrally entirely yellow as included in Mickel's (1935) key.

\section{Arkaditilla frim sp. nov.}

http://zoobank.org/E5FFF6B3-52AC-49E9-8B78-B07E69973CFF

Figures 5, 6, 15, 21, 29, 30, 41, 42, 55-57, 69, 75

Diagnosis. Male. Clypeus dorsally elevated, sloping ventrally. Mandible with weak subapical and subbasal teeth (Fig. 15), ventrally deeply excised with large basal tooth (Fig. 21). Scape ventral carinae divergent apically (Fig. 29), densely punctate between them; F1 apical 1/3, F2, F3 basal half whitish yellow on ventral half, F5-F11 with ventral yellow to reddish brown patch; F1 strongly depressed, F1 height $\sim 0.8 \times$ pedicel diameter (Fig. 30). T3 orange (Fig. 6); cuspis weakly widened on posterior 1/3 with rounded apex (Figs 55, 69); digitus posteriorly expanded, forming triangular projection (Fig. 41); paracuspis slightly tuberculate (Fig. 69); penis valve weakly expanded ventrally (Figs 56, 57). Female. Unknown.

Description. Male. Body length: 11.2-15.0 mm (holotype: $15.0 \mathrm{~mm}$; mean: $13.1 \mathrm{~mm}$ ); forewing length: $8.09-10.7 \mathrm{~mm}$ (holotype: $10.7 \mathrm{~mm}$; mean: $9.37 \mathrm{~mm}$ ).

Color and setae. Frons, vertex, gena, clypeus, pedicel, flagellum mostly, prementum, stipes, mesosoma, T4-T7, S4-S8 black; mandible brown to black, with apex always black and medial 1/5-1/2 yellowish brown; labrum, protibial spur yellow; scape, tegula brownish black; F1 apical 1/3, F2, F3 basal half whitish yellow on ventral half; F5-F11 yellow to reddish brown ventrally; trochanters brown to dark brown; coxae, femora, tibiae, tarsi dark brown to brownish black; meso- and metatibial spurs pale yellow; T1-T3, S1-S3 orange; wings pale brown on proximal $1 / 3$, brown on distal $2 / 3$, with veins dark brown. Upper frons, vertex, trochanters, T1, S1 with sparse long erect pale golden setae; lower frons, dorsal propodeal face, dorsal half of lateral propodeal face with dense short appressed and sparse long erect pale golden setae; eye dorsal margin with long erect black setae; gena, pronotal dorsum, metascutellum with sparse short recumbent and sparse long erect pale golden setae; clypeus with dense long recumbent pale golden setae; mandible, tibiae, tarsi, T2-T5 with sparse long recumbent 


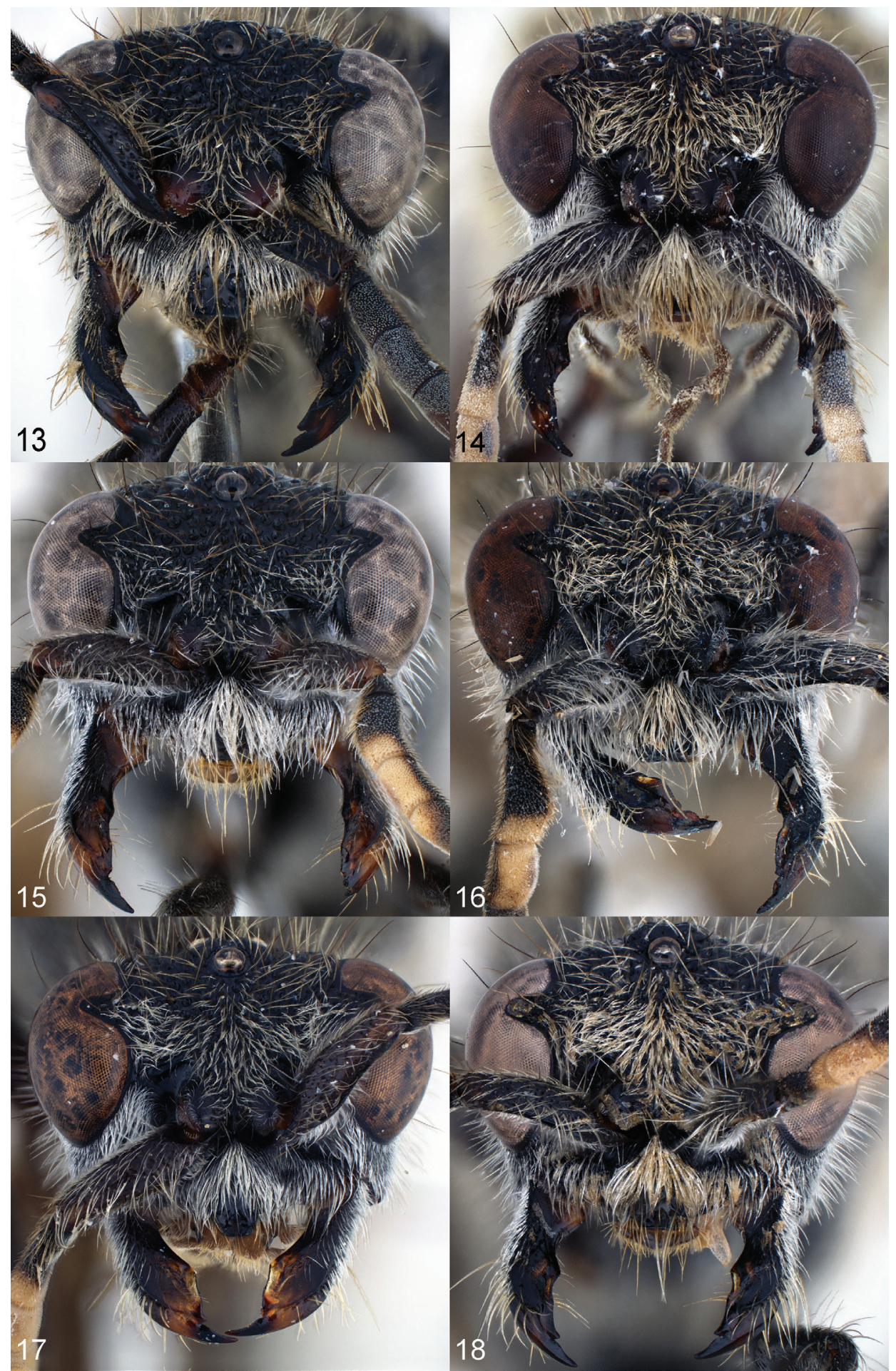

Figures I3-18. Arkaditilla spp., Ô, face 13 A. bagrada (Cameron) I4 A. depressicornis (Mickel) I5 A. frim sp. nov., holotype $\mathbf{1 6}$ A. gibba sp. nov., paratype $\mathbf{1 7}$ A. leleji sp. nov., holotype $\mathbf{1 8}$ A. nallinia (Zavattari). 
pale golden setae; scape, femora, S2 with sparse long recumbent and sparse long erect pale golden setae; pedicel, F1, tegula anterior portion with sparse short recumbent pale golden setae; F2-F11 with sparse erect pale golden microsetae; pronotal collar anteriorly, T2 disc, T3-T5 medially, S3-S6 with sparse short erect pale golden setae; pronotal collar posteriorly glabrous; pronotal lateral face meso- and metacoxae with sparse long appressed pale golden setae; propleuron with sparse long appressed and sparse long erect pale golden setae; mesoscutum with sparse short recumbent black and sparse short erect pale golden to black setae; tegula inner margin with sparse short recumbent pale golden and sparse short erect pale golden to black setae; mesoscutellum with sparse short recumbent pale golden, sparse long erect black, sparse long erect pale golden setae; anterior and posterior parts of mesopleuron, metapleuron, ventral half of lateral propodeal face with sparse short appressed pale golden setae; axilla, metanotal trough, medial and ventral parts of mesopleuron, procoxa with dense long appressed and sparse long erect pale golden setae; T6-T7, S7-S8 with sparse long recumbent and sparse long erect black setae; T2 with lateral golden felt line; T1-T5, S2-S5 with posterior fringe of sparse pale golden setae; S6-S8 with posterior fringe of sparse black setae.

Structure. Head 1.82-2.00x as wide as long (holotype: 2.00); lateral margins strongly convergent behind eye; vertex rounded posteriorly; $\mathrm{POD} / \mathrm{OOD}=0.56$ 0.58 (holotype: 0.56); OD:MOD:LOD = 1.00:1.08-1.12:0.94-1.00 (holotype: 1.00:1.12:0.94); ocellar region slightly convex, ocelli without posterior carina; antennal scrobe with weak inverted V-shaped dorsal carina not reaching inner eye margin; genal carina absent; postgenal bridge flattened; hypostomal carina weakly developed; clypeus dorsally elevated, sloping ventrally, with subventral transverse groove laterally not defined by carina; anterior clypeal margin projecting medially; mandible robust, narrowed to apex with inner margin expanded forming small subbasal tooth; mandible apex bidentate; mandible ventral margin excised into large basal tooth; mandible dorsal carina sharp; prementum flattened; scape curved medially, with two longitudinal ventral carinae divergent apically; F1 depressed, F1 height $0.67-0.80 \times$ pedicel diameter (holotype: 0.67); relative length of pedicel, F1 and F2 = 1.00:2.85-3.06:1.92-2.29 (holotype: 1.00:3.06:2.29); F2-F11 almost equal in width; F11 as long as F2, conical.

Mesosoma widest at mesonotum including tegulae; head width:humeral width:pronotal width:mesonotal width $=88: 62: 91: 100$; humeral angle rounded, with sharp humeral carina on ventral half; mesoscutum strongly convex; mesoscutal width $1.12 \times$ its length; tegula short rounded, posteriorly reaching mesoscuto-scutellar articulation, 1.44-1.53x as long as wide (holotype: 1.53); notaulus evenly wide, reaching anterior $1 / 2$ of mesoscutum, subparallel; parapsidal line length $0.25 \times$ mesoscutal length; parascutal carina forming rounded, weakly elevated process on postero-lateral angle of mesoscutum; mesoscutellum convex without medial carina, tubercle or impunctate line; mesopleuron divided into dorsal and ventral convexities by distinct transverse mesopleural groove, ventrally without transverse precoxal ridge, longitudinal impunctate line, or precoxal swelling; dorsal propodeal face without distinct dorsum and sublateral carina, with anterior inverted triangular cell and semicircular sublateral cell; lateral margins of propodeum gradually convergent posteriorly; dorsal and lateral propodeal faces not separated by carina. 
Wings well developed; distance between origin of RS on vein SC and base of stigmatic cell equal to stigmatic cell length and first abscissa of RS length; cell $2 \mathrm{RS}$ present.

Meso- and metacoxae evenly convex; metacoxa with weak complete inner longitudinal carina; protibial spur slender; tibiae without outer spines.

T1 without distinct dorsum; T1 spiracle weakly tuberculate; T2 evenly convex, $1.28 \times$ as wide as long; $\mathrm{S} 1$ with straight medial longitudinal carina with its ventral margin slightly elevated posteriorly; S2 swollen anteriorly; T7 medially with longitudinal impunctate convex line, posteriorly not forming tubercle; S6-S8 without lateral carina or tubercle; S7 entirely exposed, $0.75 \times$ as long as S8; S8 mostly sclerotized with posterior membranous area evenly convex posteriorly. Paramere down-curved posteriorly, with weak inner protuberance on posterior $1 / 2$ of dorso-inner margin; inner margin of paramere dorsally with short erect golden setae; ventral lobe posteriorly projecting, pointed; parapenial lobe large, with posterior margin slightly concave; cuspis long slender, weakly widened on posterior $1 / 3$ with rounded apex, slightly surpassing apex of penis valve, with dense long erect setae ventrally and posteriorly; digitus straight, posteriorly expanded, forming triangular projection, with dense erect golden setae posteriorly; paracuspis slightly tuberculate with few erect golden setae; penis valves symmetrical slender, weakly expanded ventrally, with posterior ventral hook, without setae.

Frons, vertex, gena, pronotal dorsum, mesoscutum, medial part of mesopleuron with large dense punctures; postgenal bridge, clypeus lateral portion, mandible outer face, scape between ventral carinae, flagellum, pronotal lateral face, propleuron, axilla, metanotal trough, anterior and posterior parts of mesopleuron, metapleuron, ventral half of lateral propodeal face, procoxa, tarsi with minute dense punctures; clypeus medial convexity with large sparse punctures; mandible mostly, pronotal collar posteriorly smooth; scape mostly, trochanters, femora, tibiae, T1 medially, T2 disc, T3-T6, S1-S2 with small sparse punctures; pedicel, pronotal collar anteriorly, meso- and metacoxa with minute sparse punctures; mesoscutellum with large confluent punctures; metascutellum with small confluent punctures; dorsal propodeal face, dorsal half of lateral propodeal face reticulate; T1-T2 laterally, T7, S3-S8 with small dense punctures; tegula mostly microreticulate with few small punctures anteriorly, postero-inner portion with minute sparse punctures.

Type material. 20. Holotype ${ }^{\top}$ : Malaysia: Negeri Sembilan: Pasoh Forest Reserve, 3-10.XII.1993, K. Maeto leg., coarse Malaise trap, plot 6 [FRIM]. Paratype: Malaysia: Negeri Sembilan: Pasoh Forest Reserve, 25.III-2.IV.1993, K. Konishi \&

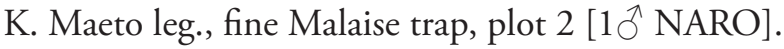

Distribution. Malaysia: Negeri Sembilan.

Etymology. This new species is named after FRIM, Forest Research Institute Malaysia, which was the Malaysian counterpart of the Japan-Malaysia joint research project in 1993 funded by the Ministry of the Environment of Japan. Treat as a noun in apposition.

Remarks. This species occurs sympatrically with $A$. depressicornis, but this new species differs from it by having the mandible with weakly developed subbasal and subapical teeth (subbasal and subapical teeth large in $A$. depressicornis), the digitus posteriorly expanded (digitus slender in $A$. depressicornis), and the paracuspis tuberculate (paracuspis absent in $A$. depressicornis). 


\section{Arkaditilla gibba sp. nov.}

http://zoobank.org/25D8F0E2-795C-4BC7-BDAB-461B910EE8A9

Figures 7, 8, 16, 22, 31, 32, 43, 44, 58-60, 70, 75

Diagnosis. Male. Clypeus medially strongly elevated even ventrally. Mandible with sharp subapical and large inner subbasal teeth (Fig. 16), ventrally deeply excised with large basal tooth (Fig. 22). Scape ventral carinae divergent apically (Fig. 31), densely punctate between them; F1 apical 1/3 and F2 whitish yellow on ventral half; F1 strongly depressed, F1 height $-0.8 \times$ pedicel diameter (Fig. 32). T3 orange (Fig. 8); cuspis widened near apex, forming oblique posterior margin (Figs 58, 70); digitus posteriorly expanded, forming triangular projection (Fig. 43); paracuspis slightly tuberculate (Fig. 70); penis valve weakly expanded ventrally (Figs 59, 60). Female. Unknown.

Description. Male. Body length: 12.4-15.1 mm (holotype: $12.4 \mathrm{~mm}$; mean: $13.8 \mathrm{~mm}$ ); forewing length: 10.6-11.0 mm (holotype: $10.6 \mathrm{~mm}$; mean: $10.8 \mathrm{~mm}$ ).

Color and setae. Frons, vertex, gena, clypeus, mandible mostly, scape, pedicel, flagellum mostly, prementum, stipes, mesosoma, coxae, femora, tibiae, tarsi, T4-T7, S1 medial carina, S4-S8 black; mandible medial 1/4 reddish brown; F1 apical 1/3, F2 whitish yellow on ventral half; labrum, tegula brownish black; trochanters, protibial spur dark brown; meso- and metatibial spurs pale yellow; T1-T3, S1 except medial carina, S2-S3 orange; wings pale brown, with veins dark brown. Upper frons, vertex, T1, S1 with sparse long erect pale golden setae; lower frons, pronotal dorsum, dorsal propodeal face, dorsal half of lateral propodeal face with dense short appressed and sparse long erect pale golden setae; gena, femora, tibiae with sparse short recumbent and sparse long erect pale golden setae; eye dorsal margin with long erect black setae; clypeus with dense long recumbent pale golden setae; mandible, trochanters, T2 lateral margin with sparse long recumbent pale golden setae; scape with sparse long recumbent and sparse long erect pale golden setae; pedicel, F1 with sparse short recumbent pale golden setae; F2-F11 with sparse erect pale golden microsetae; pronotal collar anteriorly, T2 disc, T3-T5, S3-S6 with sparse short erect pale golden setae; pronotal collar posteriorly glabrous; pronotal lateral face, coxae with sparse long appressed pale golden setae; propleuron with sparse long appressed and sparse long erect pale golden setae; mesoscutum with sparse short recumbent and sparse short erect goldish black setae; mesoscutellum, metascutellum with sparse short recumbent pale golden and sparse long erect pale golden to blackish golden setae; axilla, metanotal trough with dense long appressed pale golden setae; anterior and posterior parts of mesopleuron, metapleuron, ventral half of lateral propodeal face with sparse short appressed pale golden setae; medial and ventral parts of mesopleuron with dense long appressed and sparse long erect pale golden setae; tegula anterior portion, tarsi with sparse long recumbent pale golden setae; tegula inner margin with sparse short recumbent and sparse short erect golden setae; $S 2$ with sparse short recumbent and sparse short erect pale golden setae; T6-T7, S7-S8 with sparse short erect black setae; T2 with lateral golden felt line; T1-T5, S2-S5 with posterior fringe of sparse pale golden setae; S6-S8 with posterior fringe of sparse black setae. 

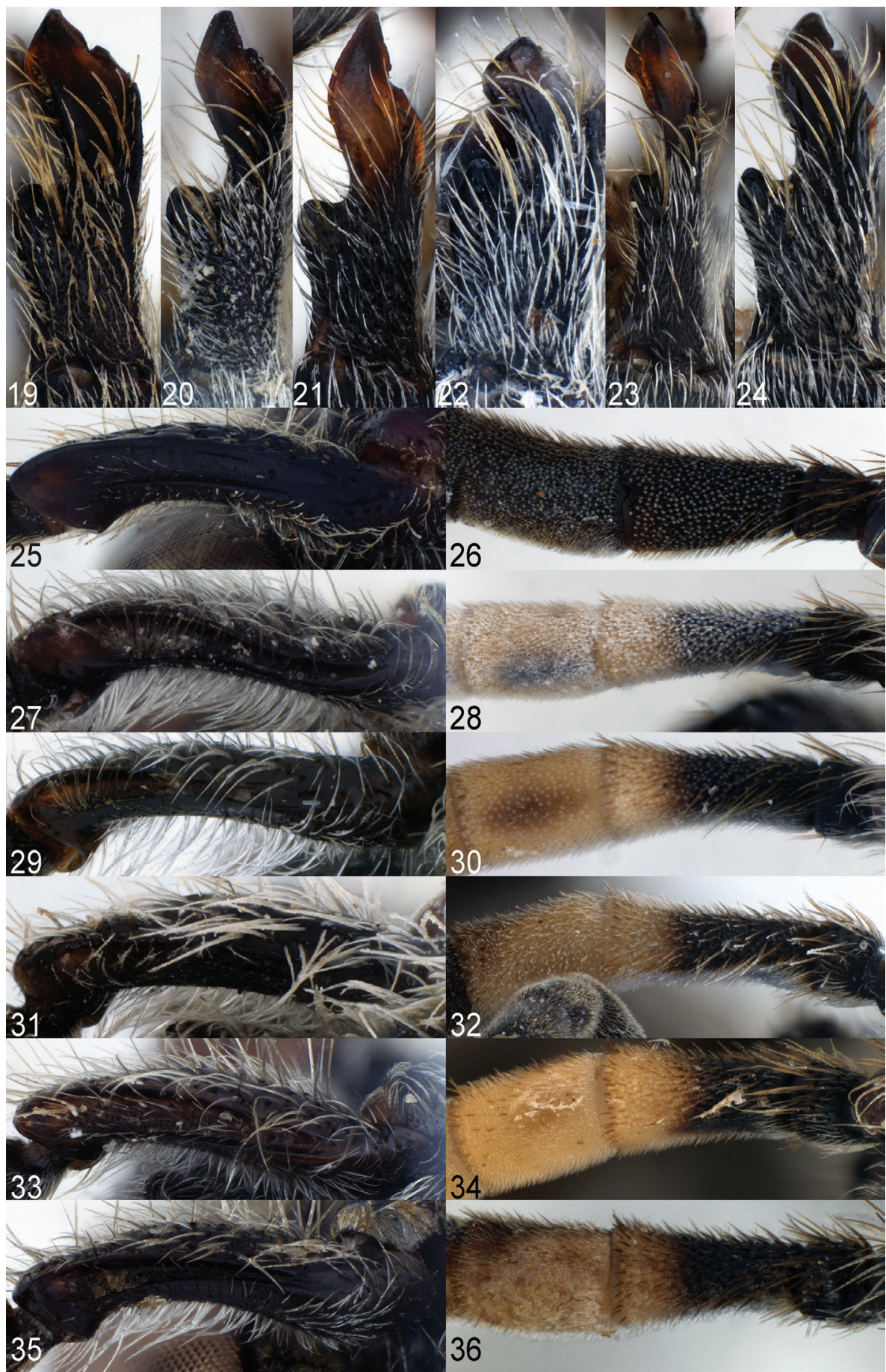

Figures 19-36. Arkaditilla spp., ô 19-24 mandible, lateral view 25, 27, 29, 31, 33, 35 scape, ventral view 26, 28, 30, 32, 34, 36 pedicel, F1, and F2, lateral view 19, 25, 26 A. bagrada (Cameron) 20, 27, 28 A. depressicornis (Mickel) 21, 29, 30 A. frim sp. nov., holotype 22, 31, 32 A. gibba sp. nov., holotype 23, 33, 34 A. leleji sp. nov., holotype 24, 35, 36 A. nallinia (Zavattari). 
Structure. Head 1.89-1.92× as wide as long (holotype: 1.92); lateral margins strongly convergent behind eye; vertex rounded posteriorly; $\mathrm{POD} / \mathrm{OOD}=0.56$ 0.77 (holotype: 0.77); OD:MOD:LOD = 1.00:1.15-1.58:0.92-1.08 (holotype: 1.00:1.58:0.92); ocellar region slightly convex, ocelli without posterior carina; antennal scrobe with weak inverted V-shaped dorsal carina not reaching inner eye margin; genal carina absent; postgenal bridge flattened; hypostomal carina weakly developed; clypeus medially strongly elevated even ventrally, without subventral transverse groove; anterior clypeal margin projecting medially; mandible robust, narrowed to apex with inner margin expanded forming large subbasal tooth; mandible apex bidentate; mandible ventral margin excised into large basal tooth; mandible dorsal carina sharp; prementum flattened; scape curved medially, with two longitudinal ventral carinae divergent apically; F1 depressed, F1 height $0.75 \times$ pedicel diameter; relative length of pedicel, F1 and F2 = 1.00:3.00-3.05:1.84-2.26 (holotype: 1.00: 3.05:1.84); F2-F11 almost equal in width; F11 as long as F2, conical.

Mesosoma widest at mesonotum including tegulae; head width:humeral width:pronotal width:mesonotal width $=87: 60: 93: 100$; humeral angle rounded, with sharp humeral carina not reaching pronotal dorsum; mesoscutum strongly convex; mesoscutal width $1.20 \times$ its length; tegula short rounded, posteriorly reaching mesoscuto-scutellar articulation, $1.43-1.44 \times$ as long as wide (holotype: 1.44); notaulus evenly wide, reaching anterior $1 / 2$ of mesoscutum, subparallel; parapsidal line length $0.25 \times$ mesoscutal length; parascutal carina forming rounded, weakly elevated process on postero-lateral angle of mesoscutum; mesoscutellum convex without medial carina, tubercle or impunctate line; mesopleuron divided into dorsal and ventral convexities by distinct transverse mesopleural groove, ventrally without transverse precoxal ridge, longitudinal impunctate line, or precoxal swelling; dorsal propodeal face without distinct dorsum and sublateral carina, with anterior inverted triangular cell and semicircular sublateral cell; lateral margins of propodeum gradually convergent posteriorly; dorsal and lateral propodeal faces not separated by carina.

Wings well developed; distance between origin of RS on vein SC and base of stigmatic cell equal to stigmatic cell length and first abscissa of RS length; cell $2 \mathrm{RS}$ present.

Meso- and metacoxae evenly convex; metacoxa with weak complete inner longitudinal carina; protibial spur slender; tibiae without outer spines.

T1 without distinct dorsum; T1 spiracle weakly tuberculate; T2 evenly convex, $1.25 \times$ as wide as long; S1 with straight medial longitudinal carina with its ventral margin convex; S2 swollen anteriorly; T7 medially with longitudinal impunctate convex line, posteriorly not forming tubercle; S6-S8 without lateral carina or tubercle; S7 entirely exposed, $0.75 \times$ as long as S8; S8 mostly sclerotized with posterior membranous area evenly convex posteriorly. Paramere down-curved posteriorly, with weak inner protuberance on posterior $1 / 2$ of dorso-inner margin; inner margin of paramere dorsally with short erect golden setae; ventral lobe posteriorly projecting, pointed; parapenial lobe large, with posterior margin concave; cuspis long slender, widened near apex, forming oblique posterior margin, apparently surpassing apex of penis valve, with dense long erect setae ventrally and posteriorly; digitus straight, posteriorly expanded, forming triangular projection, with dense erect golden setae posteriorly; para- 
cuspis slightly tuberculate with few erect golden setae; penis valves symmetrical slender, weakly expanded ventrally, with posterior ventral hook, without setae.

Frons, vertex, gena, pronotal dorsum, mesoscutum, medial part of mesopleuron with large dense punctures; postgenal bridge, trochanters, femora, tibiae, T1 medially, T2 disc, S2 with small sparse punctures; clypeus lateral portion, mandible outer and dorsal faces, scape between ventral carinae, flagellum, pronotal lateral face, propleuron, axilla, metanotal trough, anterior and posterior parts of mesopleuron, metapleuron, ventral half of lateral propodeal face, coxae, tarsi with minute dense punctures; clypeus medial convexity, scape mostly, pedicel, T1-T2 laterally, T3-T7, S1, S3-S8 with small dense punctures; mesoscutellum with large confluent punctures; metascutellum with small confluent punctures; dorsal propodeal face, dorsal half of lateral propodeal face reticulate; pronotal collar anteriorly with minute sparse punctures; pronotal collar posteriorly smooth; tegula mostly microreticulate with few small punctures anteriorly, postero-inner portion with minute sparse punctures.

Type material. $2{ }^{\lambda}$. Holotype ${ }^{\lambda}$ : IndONESIA: EAST JAVA: Mt. Argopuro, 31.VII.1995 [TKPM]. Paratype: Indonesia: East Java: Mt. Argopuro, 31.VII.1995 [1 $\delta^{\lambda}$ TKPM].

Distribution. Indonesia: East Java.

Etymology. The specific name gibba is a Latin noun meaning gibbosity. It refers to the strongly elevated clypeus of this new species.

Remarks. This species and A. nallinia are recognized in Arkaditilla by having the mandible with sharp subapical and large inner subbasal teeth, the mandible ventral margin deeply excised with large basal tooth, the scape ventral carinae divergent apically, F1 strongly depressed, the cuspis widened posteriorly, the digitus posteriorly expanded, the paracuspis tuberculate, and the penis valve weakly expanded ventrally, but the former differs from the latter by having the clypeus strongly elevated even ventrally (clypeus elevated dorsally in A. nallinia), and the cuspis widened near apex (cuspis widened on posterior $1 / 3$ in $A$. nallinia).

\section{Arkaditilla leleji sp. nov.}

http://zoobank.org/1A4CD8F4-673F-40E8-8A9A-D12E0DBFFE0A

Figures 9, 10, 17, 23, 33, 34, 45, 46, 61-63, 71, 75

Diagnosis. Male. Clypeus dorsally elevated, sloping ventrally. Mandible with sharp subapical and large inner subbasal teeth lamellately expanded near apex (Fig. 17), ventrally slightly excised with small basal tooth (Fig. 23). Scape ventral carinae divergent apically (Fig. 33), densely punctate between them; F1 apical half and F2-F6 whitish yellow on ventral half, F7-F11 with ventral dark brown patch; F1 weakly depressed, F1 height subequal to pedicel diameter (Fig. 34). T3 black (Fig. 10); cuspis weakly widened on posterior $1 / 3$ with rounded apex (Figs 61,71); digitus posteriorly slender stick-like (Fig. 45); paracuspis slightly tuberculate (Fig. 71); penis valve strongly expanded ventrally on posterior half (Figs 62, 63). Female. Unknown.

Description. Male. Body length: $15.9 \mathrm{~mm}$; forewing length: $13.0 \mathrm{~mm}$. 


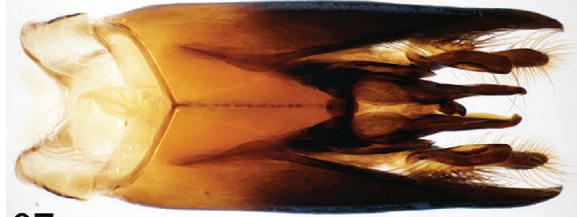

37

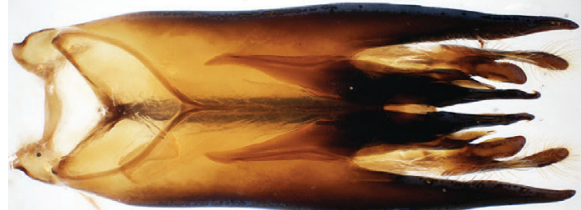

39

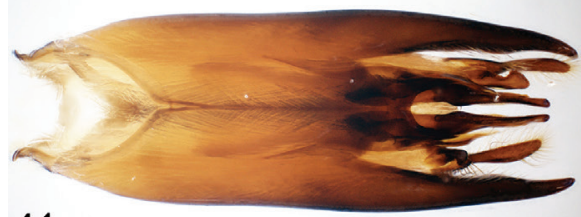

41

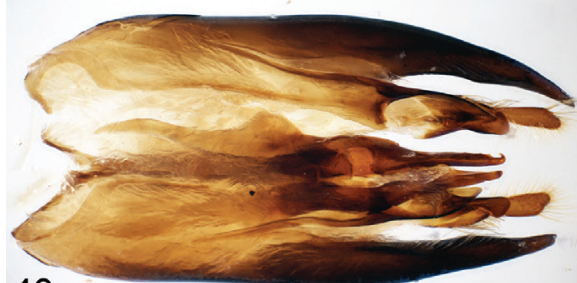

43

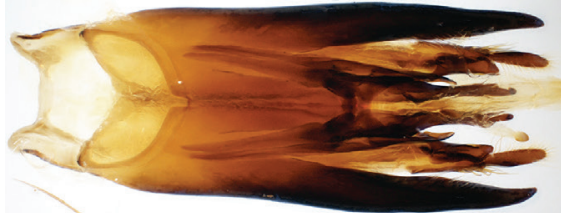

45

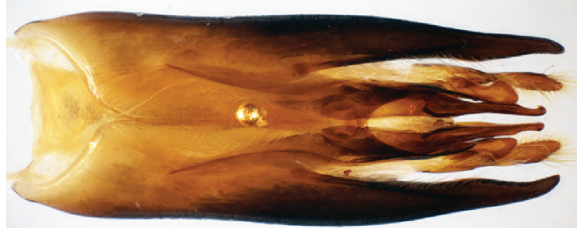

47
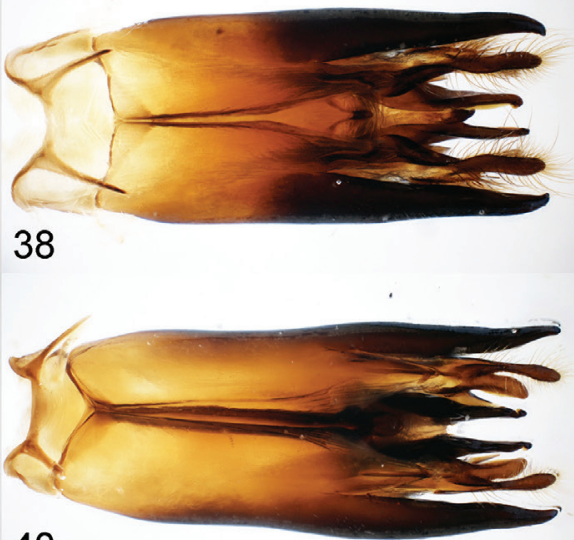

40

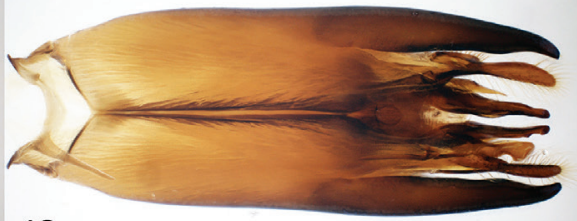

42
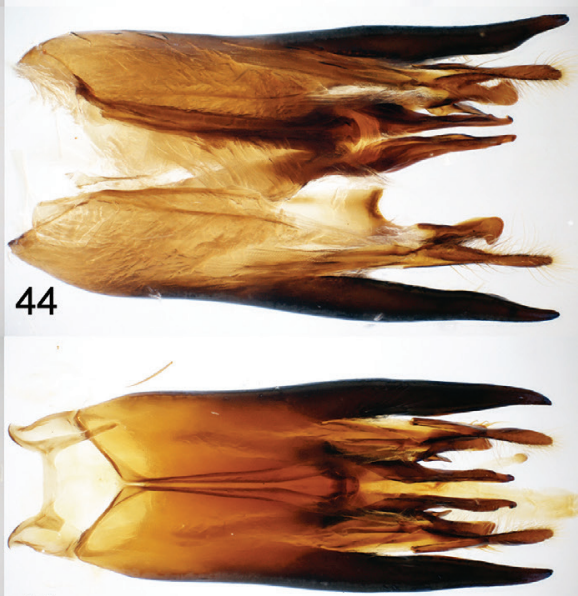

46

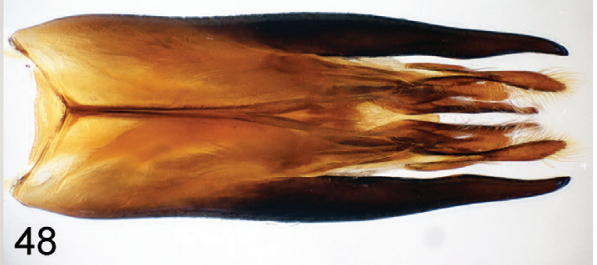

Figures 37-48. Arkaditilla spp., Ô, genitalia 37, 39, 4I , 43, 45, 47 dorsal view 38, 40, 42, 44, 46, 48 ventral view 37, 38 A. bagrada (Cameron) 39, 40 A. depressicornis (Mickel) 41, 42 A. frim sp. nov., holotype 43,44 A. gibba sp. nov., holotype 45, 46 A. leleji sp. nov., holotype 47, 48 A. nallinia (Zavattari). 
Color and setae. Frons, vertex, gena, clypeus, mandible mostly, pedicel, flagellum mostly, prementum, stipes, mesosoma, meso- and metacoxae, T3-T7, S1 medial carina, S4-S8 black; mandible medial 1/3 brown; labrum, protibial spur yellow; scape, F7-F11 ventrally, trochanters dark brown; F1 apical half, F2-F6 whitish yellow on ventral half; tegula, procoxa, femora, tibiae, tarsi, S3 lateral portion brownish black; meso- and metatibial spurs pale yellow; T1-T2, S1 except medial carina, S2-S3 mostly orange; wings brown, with veins dark brown. Upper frons, vertex, T1, S1 with sparse long erect pale golden setae; lower frons, gena, pronotal dorsum, dorsal propodeal face, dorsal half of lateral propodeal face, coxae with dense short appressed and sparse long erect pale golden setae; eye dorsal margin with long erect black setae; clypeus with dense long recumbent pale golden setae; mandible with sparse short recumbent and sparse long erect pale golden setae; scape with sparse long recumbent and sparse long erect pale golden setae; pedicel, F1, trochanters, T2 lateral margin with sparse short recumbent pale golden setae; F2-F11 with sparse erect pale golden microsetae; pronotal collar anteriorly, T2 disc, T3-T5, S3-S6 with sparse short erect pale golden setae; pronotal collar posteriorly glabrous; pronotal lateral face with sparse long appressed pale golden setae; propleuron with sparse long appressed and sparse long erect pale golden setae; mesoscutum with sparse short recumbent and sparse short erect dark golden setae; meso- and metascutellum, femora with sparse short recumbent pale golden and sparse long erect golden setae; anterior and posterior parts of mesopleuron, metapleuron, ventral half of lateral propodeal face with sparse short appressed pale golden setae; axilla, metanotal trough, medial and ventral parts of mesopleuron with dense long appressed and sparse long erect pale golden setae; tegula anterior portion, tarsi with sparse long recumbent golden setae; tegula inner margin with sparse short recumbent and sparse short erect golden setae; tibiae with sparse short recumbent golden and sparse long erect golden setae; T6-T7, S7-S8 with sparse short erect black setae; S2 with sparse short recumbent and sparse short erect pale golden setae; T2 with lateral golden felt line; T1-T5, S2-S5 with posterior fringe of sparse pale golden setae; S6-S8 with posterior fringe of sparse black setae.

Structure. Head $2.00 \times$ as wide as long; lateral margins strongly convergent behind eye; vertex rounded posteriorly; $\mathrm{POD} / \mathrm{OOD}=0.54 ;$ OD:MOD:LOD = 1.00:1.29:1.00; ocellar region slightly convex, ocelli without posterior carina; antennal scrobe with weak inverted $\mathrm{V}$-shaped dorsal carina not reaching inner eye margin; genal carina absent; postgenal bridge flattened; hypostomal carina weakly developed; clypeus dorsally elevated, sloping ventrally, without subventral transverse groove; anterior clypeal margin projecting medially; mandible robust, narrowed to apex with inner margin expanded forming large subbasal tooth; mandible apex bidentate; mandible ventral margin slightly excised into small basal tooth; mandible dorsal carina sharp; prementum flattened; scape curved medially, with two longitudinal ventral carinae divergent apically; F1 depressed, F1 height $0.91 \times$ pedicel diameter; relative length of pedicel, F1 and F2 = 1.00:3.00:2.37; F2-F11 almost equal in width; F11 as long as F2, conical.

Mesosoma widest at mesonotum including tegulae; head width:humeral width:pronotal width:mesonotal width $=83: 62: 85: 100$; humeral angle rounded, with sharp humeral carina not reaching pronotal dorsum; mesoscutum strongly convex; 


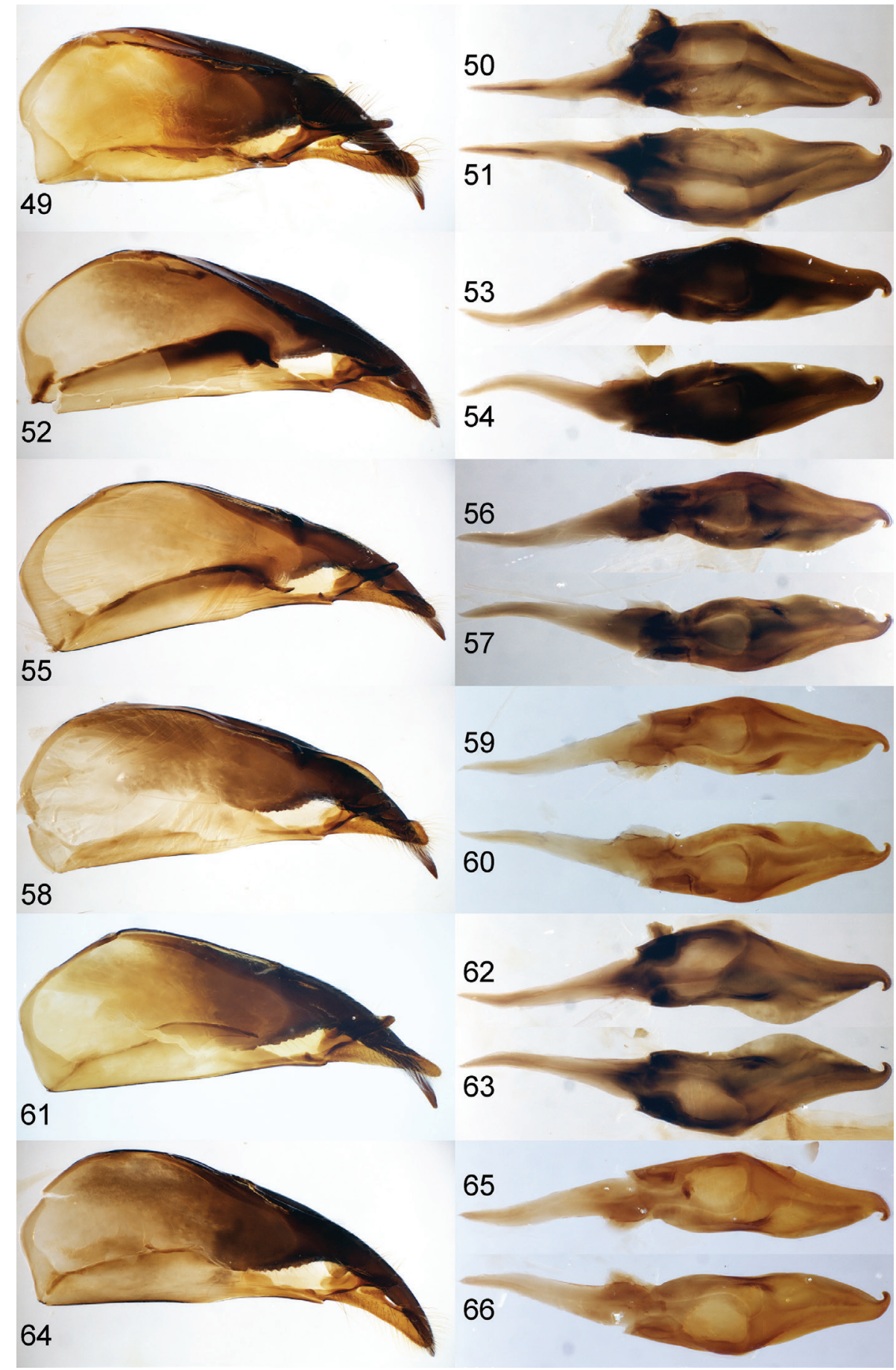

Figures 49-66. Arkaditilla spp., đ̂, genitalia 49, 52, 55, 58, 61, 64 genital capsule and volsella, inner view 50, 53, 56, 59, 62, 65 left penis valve 5I, 54, 57, 60, 63, 66 right penis valve 49-5 I A. bagrada (Cameron) 52-54 A. depressicornis (Mickel) 55-57 A. frim sp. nov., holotype 58-60 A. gibba sp. nov., holotype 6I-63 A. leleji sp. nov., holotype 64-66 A. nallinia (Zavattari). 
mesoscutal width $1.11 \times$ its length; tegula short rounded, posteriorly reaching mesoscuto-scutellar articulation, $1.54 \times$ as long as wide; notaulus evenly wide, reaching anterior $1 / 2$ of mesoscutum, subparallel; parapsidal line length $0.3 \times$ mesoscutal length; parascutal carina forming rounded, weakly elevated process on postero-lateral angle of mesoscutum; mesoscutellum convex without medial carina, tubercle or impunctate line; mesopleuron divided into dorsal and ventral convexities by distinct transverse mesopleural groove, ventrally with transverse precoxal ridge, without longitudinal impunctate line, or precoxal swelling; dorsal propodeal face without distinct dorsum and sublateral carina, with anterior inverted triangular cell and semicircular sublateral cell; lateral margins of propodeum gradually convergent posteriorly; dorsal and lateral propodeal faces not separated by carina.

Wings well developed; distance between origin of RS on vein SC and base of stigmatic cell equal to stigmatic cell length and first abscissa of RS length; cell 2RS present.

Meso- and metacoxae evenly convex; metacoxa with weak complete inner longitudinal carina; protibial spur slender; tibiae without outer spines.

T1 without distinct dorsum; T1 spiracle weakly tuberculate; T2 evenly convex, $1.15 \times$ as wide as long; S1 with straight medial longitudinal carina with its ventral margin convex; S2 swollen anteriorly; T7 medially with longitudinal impunctate convex line, posteriorly not forming tubercle; S6-S8 without lateral carina or tubercle; S7 entirely exposed, $0.75 \times$ as long as S8; S8 mostly sclerotized with posterior membranous area evenly convex posteriorly. Paramere down-curved posteriorly, without inner protuberance on dorso-inner margin; inner margin of paramere dorsally with short erect golden setae; ventral lobe posteriorly projecting, pointed; parapenial lobe large, with posterior margin slightly concave; cuspis long slender, weakly widened on posterior 1/3 with rounded apex, apparently surpassing apex of penis valve, with dense long erect setae ventrally and posteriorly; digitus straight, posteriorly not expanded, with dense erect golden setae posteriorly; paracuspis slightly tuberculate with few erect golden setae; penis valves symmetrical slender, strongly expanded ventrally on posterior half, with posterior ventral hook, without setae.

Frons, vertex, gena, pronotal dorsum, mesoscutum, medial part of mesopleuron with large dense punctures; postgenal bridge, trochanters, femora, tibiae, T1 medially, T2 disc with small sparse punctures; clypeus mostly, mandible outer and dorsal faces, scape between ventral carinae, flagellum, pronotal lateral face, propleuron, axilla, metanotal trough, anterior and posterior parts of mesopleuron, metapleuron, ventral half of lateral propodeal face, coxae, tarsi with minute dense punctures; clypeus anterior margin with few large punctures; scape mostly, pedicel, T1-T2 laterally, T3-T7, S1-S8 with small dense punctures; pronotal collar anteriorly with minute sparse punctures; pronotal collar posteriorly smooth; mesoscutellum with large confluent punctures; metascutellum with small confluent punctures; dorsal propodeal face, dorsal half of lateral propodeal face reticulate; tegula mostly microreticulate with few small punctures anteriorly, postero-inner portion with minute sparse punctures.

Type material. 1 $\hat{\jmath}$. Holotype $\hat{\jmath}$ : Indonesia: Kalimantan Timur: Bukit Soeharto, 13-17.III.1994, K. Matsumoto \& K. Konishi leg. [NARO]. 


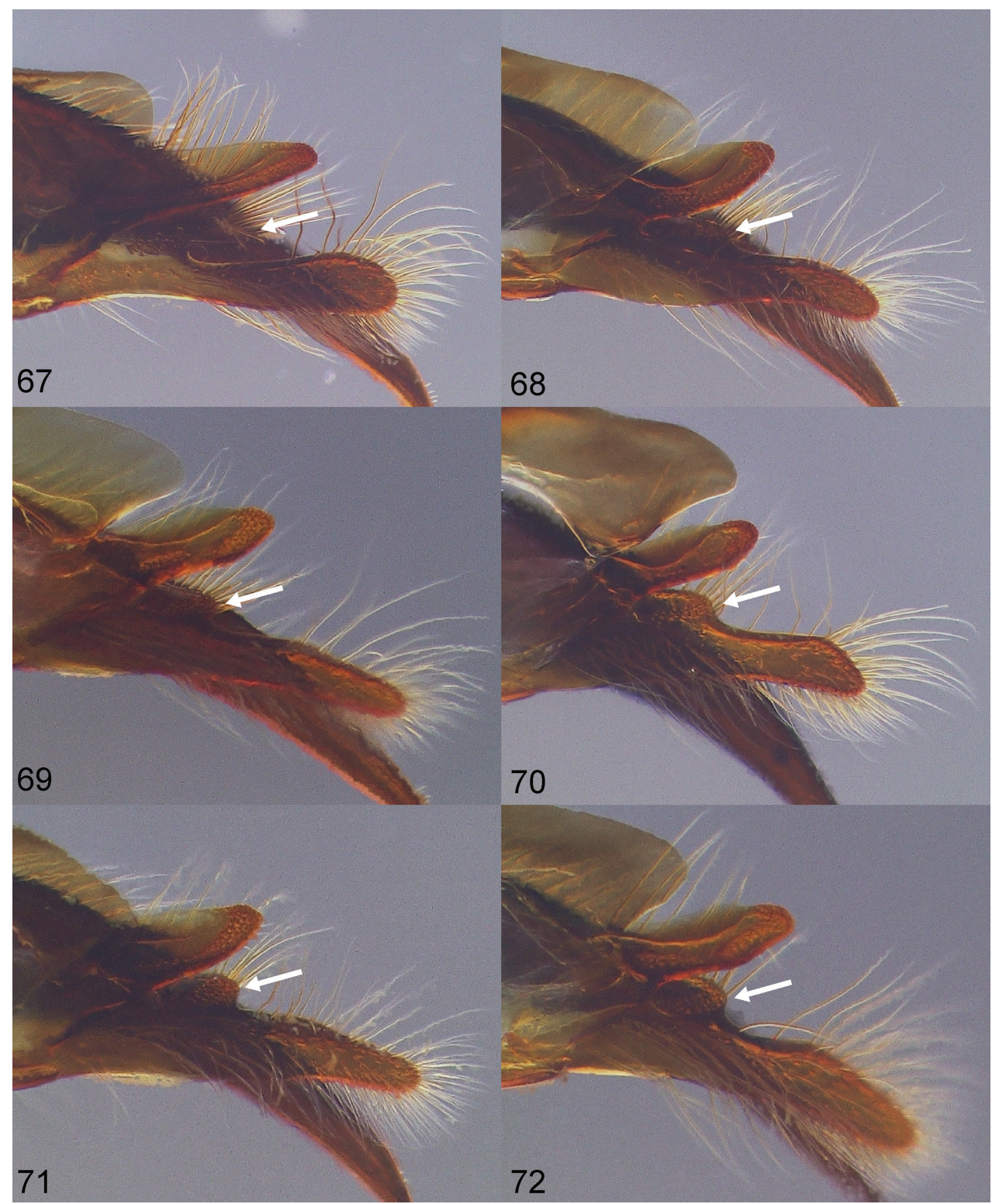

Figures 67-72. Arkaditilla spp., $\hat{\jmath}$, genital volsella, ventro-inner view 67 A. bagrada (Cameron) 68 A. depressicornis (Mickel) 69 A. frim sp. nov., holotype 70 A. gibba sp. nov., holotype 71 A. leleji sp. nov., holotype $72 \mathrm{~A}$. nallinia (Zavattari). White arrows indicate the paracuspis.

Distribution. Indonesia: Kalimantan Timur.

Etymology. This new species is dedicated to Arkady Lelej as is the genus itself.

Remarks. This new species is unique in Arkaditilla by having the mandible ventral margin slightly excised with small basal tooth, F1 weakly depressed, T3 black, and the penis valve strongly expanded ventrally on posterior half. 
Arkaditilla nallinia (Zavattari, 1914), comb. nov.

Figures 11, 12, 18, 24, 35, 36, 47, 48, 64-66, 72, 76

Mutilla nallinia Zavattari, 1914: 100, ઊ̂, syntypes ô (Giava [= Java], [Indonesia]; Bali, [Indonesia]) [Museo Regionale di Scienze Naturali, Torino, Italy].

Timulla (Trogaspidia) nallinia: Mickel, 1935: 263, ô.

Krombeinidia nallinia: Lelej 1996a: 11; 2005: 66; Lo Cascio 2015: 551; Pagliano et al. 2020: 251.

Petersenidia nallinia: Lelej 1996b: 94, §ิ.

Diagnosis. Male. Clypeus dorsally elevated, sloping ventrally. Mandible with sharp subapical and large inner subbasal teeth (Fig. 18), ventrally deeply excised with large basal tooth (Fig. 24). Scape ventral carinae divergent apically (Fig. 35), densely punctate between them; F1 apical 1/3, F2 and F3 basal 1/3 whitish yellow on ventral half; F1 strongly depressed, F1 height $\sim 0.8 \times$ pedicel diameter (Fig. 36). T3 orange (Fig. 12); cuspis strongly widened on posterior $1 / 3$ with rounded apex (Figs 64, 72); digitus posteriorly expanded, forming triangular projection (Fig. 47); paracuspis slightly tuberculate (Fig. 72); penis valve weakly expanded ventrally (Figs 65, 66). Female. Unknown.

Material examined. $2 \hat{\gamma}$. Indonesia: BaLI: Tabanan, Bengkel, Pura Batu Salahan,

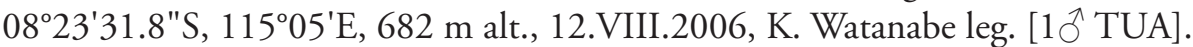

Identification source. Keyed using Mickel (1935) and compared with the original description. No differences were found between the specimen examined herein and Zavattari's description.

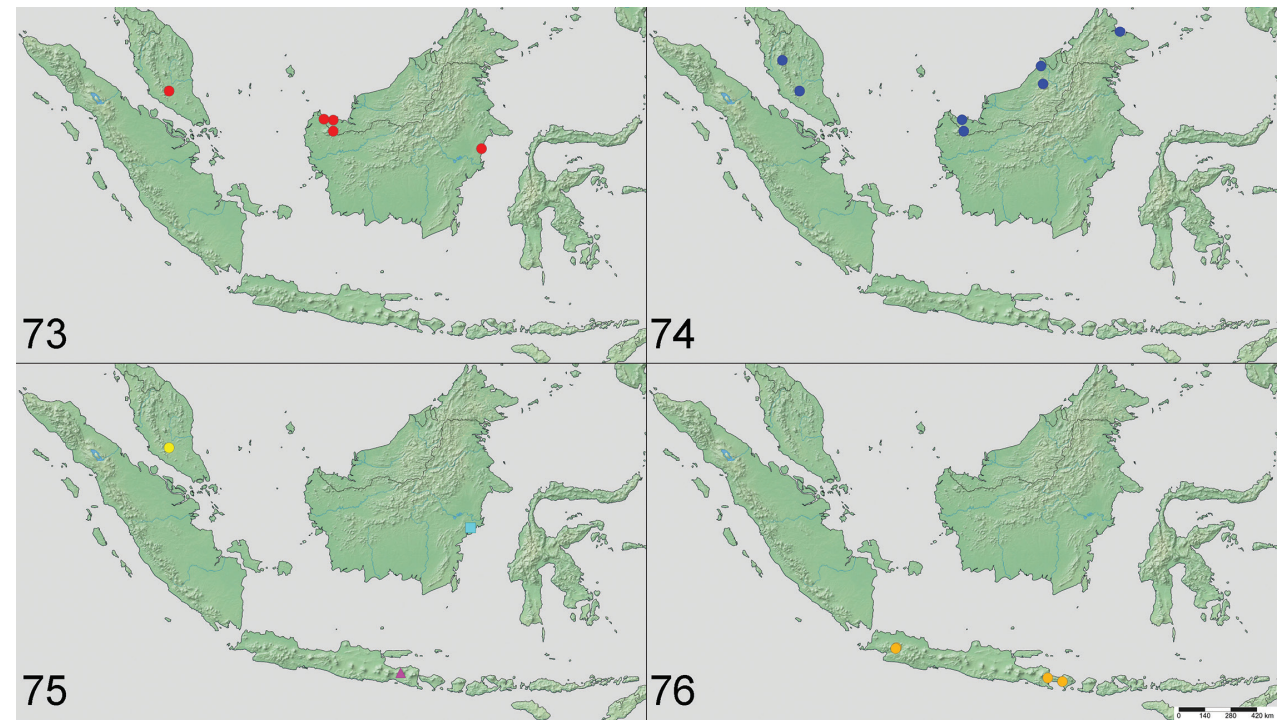

Figure 73-76. Distributional map of Arkaditilla spp. based on specimens examined herein and the literature (Cameron 1902; Lelej 1996b; Mickel 1935, 1937; Zavattari 1914) 73 A. bagrada (Cameron) (red circle) 74 A depressicornis (Mickel) (blue circle) 75 A. frim sp. nov. (yellow circle), A. gibba sp. nov. (purple triangle), and A. leleji sp. nov. (light blue square) $\mathbf{7 6}$ A. nallinia (Zavattari) (orange circle). 
Distribution. Indonesia: Bali, Java (Zavattari 1914; Mickel 1935; Lelej 1996b).

Remarks. Only three mutillid species have been recorded from Bali, namely Arkaditilla nallinia, Krombeinidia griseomaculata (André, 1898), and Mickelomyrme pusillaeformis (Hammer, 1962) (Zavattari 1914; Lelej 2005; Okayasu 2020; current data), although Zavattari's record of $K$. griseomaculata was not accepted by Lelej (2005) and Mickel (1935). Field surveys in this small island will be useful for discovery of the female of Arkaditilla.

\section{Acknowledgements}

I thank: Maxim Proshchalykin (Federal Scientific Centre for East Asian Terrestrial Biodiversity, Russian Academy of Sciences, Vladivostok, Russia) for giving me an opportunity to publish in this special issue; Denis Brothers (University of KwaZulu-Natal, Pietermaritzburg, South Africa), Kazuhiko Konishi (EUM), Kevin Williams (California Department of Food and Agriculture, Sacramento, USA), and Kazunori Yoshizawa (Hokkaido University, Sapporo, Japan) for their help in editing and publishing this paper; Nada Badruddin (FRIM), Tadashi Ishikawa (TUA), Laurence Kirton (FRIM), Kenji Ôhara (TKPM), Kazutaka Yamada (TKPM), and Junsuke Yamasako (Institute for Plant Protection, NARO) for providing access to the material discussed herein. This study is based on the material collected at the field research station of FRIM in Pasoh Forest Reserve as a part of Japan-Malaysia joint research project conducted by Laurence Kirton (FRIM), Kazuhiko Konishi (EUM), and Kaoru Maetô (Kobe University, Kobe, Japan).

\section{References}

Brothers DJ, Lelej AS (2017) Phylogeny and higher classification of Mutillidae (Hymenoptera) based on morphological reanalyses. Journal of Hymenoptera Research 60: 1-97. https:// doi.org/10.3897/jhr.60.20091

Cameron P (1902) On the Hymenoptera collected by Mr. Robert Shelford at Sarawak, and on the Hymenoptera of the Sarawak Museum. Journal of the Straits Branch of the Royal Asiatic Society 37: 29-131.

Chen C-w (1957) A revision of the velvety ants or Mutillidae of China (Hymenoptera). Quarterly Journal of the Taiwan Museum 10(3-4): 135-224. [+ 6 pls]

Hadley A (2008) CombineZM software. https://combinezm.en.lo4d.com/ [accessed 15 May 2021] Harris RA (1979) A glossary of surface sculpturing. Occasional Papers in Entomology 28: 1-31. Hymenoptera Anatomy Consortium (2021) The Hymenoptera Glossary. http://glossary.hymao.org/ [accessed 15 May 2021]

Invrea F (1954) Mutillidi della Dalmazia e del litorale Montenegrino. Nota prima. Memorie della Societa Entomologica Italiana 32: 143-159. [+ 2 figs]

Lelej AS (1971) New and little-known species of velvet ants (Hymenoptera, Mutillidae) from Middle Asia and Kazakhstan. Entomologicheskoe Obozrenie 50(3): 676-680. [+ 5 figs] [in Russian] 
Lelej AS (1995) To the knowledge of East Asian species of the tribe Smicromyrmini Bischoff, 1920 (Hymenoptera, Mutillidae) with description of four new genera and eight new species. Far Eastern Entomologist 13: 1-28.

Lelej AS (1996a) To the knowledge of the East Asian species of the tribe Trogaspidiini Bischoff, 1920 (Hymenoptera, Mutillidae) with description of eight new genera and two new species. Far Eastern Entomologist 30: 1-24.

Lelej AS (1996b) Mutillid wasps collected in Malaysia and Indonesia by Dr. Sk. Yamane (Hymenoptera, Mutillidae). Tropics 6(1-2): 91-104. https://doi.org/10.3759/tropics.6.91

Lelej AS (2005) Catalogue of the Mutillidae (Hymenoptera) of the Oriental Region. Dalnauka, Vladivostok, 252 pp.

Lelej AS, Nemkov PG (1997) Phylogeny, evolution and classification of Mutillidae (Hymenoptera). Far Eastern Entomologist 46: 1-24.

Lelej AS, Yamane Sk (1992) Interesting velvet ants (Hymenoptera, Mutillidae) from Japan and Korea. Japanese Journal of Entomology 60(3): 625-632.

Lo Cascio P (2015) Worldwide checklist of the island mutillid wasps (Hymenoptera Mutillidae). Biodiversity Journal 6(2): 529-592.

Maetô K, Fukuyama K, Kirton LG (1999) Edge effects on ambrosia beetle assemblages in a lowland rain forest, bordering oil palm plantations, in peninsular Malaysia. Journal of Tropical Forest Science 11(3): 537-547.

Mickel CE (1933a) The Mutillidae of Formosa. Annals of the Entomological Society of America 26(2): 381-423. https://doi.org/10.1093/aesa/26.2.381

Mickel CE (1933b) The Mutillidae of Eastern Asia. Lingnan Science Journal 12(3): 289-325.

Mickel CE (1934) Mutillidae of the Philippine Islands. Philippine Journal of Science 54(1): 91-219. [+ 1 pl.]

Mickel CE (1935) The mutillid wasps of the islands of the Pacific Ocean (Hymenoptera, Mutillidae). Transactions of the Royal Entomological Society of London 83(2): 177-312. https://doi.org/10.1111/j.1365-2311.1935.tb01207.x

Mickel CE (1937) New species and records of Mutillidae (Hymenoptera) from Borneo and the Solomon Islands. The Annals and Magazine of Natural History 10(19): 441-456. https:// doi.org/10.1080/00222933708655284

Okayasu J (2020) Velvet ants of the tribe Smicromyrmini Bischoff (Hymenoptera: Mutillidae) of Japan. Zootaxa 4723(1): 1-110. https://doi.org/10.11646/zootaxa.4723.1.1

Okayasu J, Lelej AS, Williams KA (2021) Review of Eotrogaspidia Lelej (Hymenoptera: Mutillidae: Trogaspidiini). Zootaxa 4920(1): 56-90. https://doi.org/10.11646/zootaxa.4920.1.2

Pagliano G, Brothers DJ, Cambra R, Lelej AS, Lo Cascio P, Matteini Palmerini M, Scaramozzino PL, Williams KA, Romano M (2020) Checklist of names in Mutillidae (Hymenoptera), with illustrations of selected species. Bollettino del Museo Regionale di Scienze Naturali di Torino 36(1-2): 5-425.

Shorthouse DP (2010) SimpleMappr, an online tool to produce publication-quality point maps. http://www.simplemappr.net [accessed 15 May 2021]

Zavattari E (1914) Mutille Austro-Malesi. Bollettino della Societa Entomologica Italiana 45: 61-114. 